Patents: An Argument in Favor of a Compulsorg License Patent Law. By J. Campbell Delano. Textile Colorist, Vol. 36, 1914. No. 432 , pp. $365-7$

Photography: Kolloidchemie und Photographie. By LúproCRAMER. Kolloid-Zeitschrift, Vol, 15, 1914, No. 4, pp. 164-6.

Roads: Repairing and Resurfacing Bituminous Parements. By SAMUEL H. LEA. Engineering Nev', Vol. 72, 1914, No. 27, pp. 1308-10.

Sanitation: Sanitation in Brazil. By EDWARD STUART. Americon Journal of Public Healih, Vol. 4, 1914, No. 12, pp. 1159-72.

Sewage: Advances in Sewage Disposal. By George W. Fulder. Engineering Record, Vol. 71, 1915, No. 1, pp. 10-11.

Sewage: Preliminary Report on Emscher Tanks and Kindred Sewage-Clariflcation Processes. By $\mathrm{K}$. Thumm and C. Rerchl. Engineering News, Vol. 72, 1914, No. 27, pp. 1306-8.

Silicates: Ueber die chemische oder physikalische Natur der Kolloiden wasserhaltigen Tonerdesilikate. By GEORG WIEGNER. Kolloid-Zeitschrift, Vol. 15, 1914, No. 4, pp. 167-9.

Steel: An झlectric Muffe Furnace for the Determination of Carbon and Oxygen in Steel and Tungsten Powder. By Charles Morris Johnson. Metallurgical and Chemical Engineering, Vol, 13, 1915, No. 1, pp. 17.

Steel: Mikroskopische Stahluntersuchung. By. B. Strauss. Zeitschrift für angewandie Chemie, Vol. 27, 1914, No. 96, pp. 633-44.

Steel: The Part Played by the Amorphous Phase in the Hardening of Steels. By J. C. W. HuMFrEy. Chemical News, Vol. 110, 1914, No. 2871 , pp. $271-4$.

Sulfuric Acid: Apparatus for the Concentration of Sulfuric Acid. By Wilimam Mason. Metallurgical and Chemical Engineering, Vol. 13,1915 , No. 1, pp. 17-18.
Sulfuric Acid: Die neueren Schwefelsäurekonzentratoren. By Oskar Kausch. Chemische A pparatur, Vol, 1, 1914, No. 20, pp. 272-4. Titanium: Has Titanium Any Influence on the Properties of Steel? By F. A. J. FITzGERALD. Metallurgical and Chemical Engineering. Vo1. 13, 1915, No. 1, pp. 28-9.

Tungsten: The Separation of Tungsten from Molybdenum. By E. E. MARBAKER. Journal of the American Chemical Society. Vol. 37 1915, No. 1, pp. 86-95.

Water: A Comparison between the Twenty-Degree and the Thirtyseven-Degree Plate Counts for Enumerating Bacteria in Water. By J. Boshex Thomas and Edgar A. Sandman. A merican Journal of Public Health, Vol. 4, 1914, No. 12, pp. 1179-81.

Water: Progress in Water supply. By ALIEN HAzEN. Enginecring Record, Vol. 71, 1915, No. 1, pp. 5-6.

Water: The Infuence of Reservoir Bottoms on Stored Water. By Wrison Frrch Smith. Engineering News, Vol. 72, 1914, No. 27. pp. 1289-92.

Water: The sulfate in River water. By H. S. Shelton. Chemical News, Vol. 110, 1914, No. 2874, pp. 307-8.

Water: Ueber den Blei-, Kupferund Zinkgehalt Künstlicher Mineralwässer und die Bestimmung dieser Metalle. By C. REESE AND J. DRost. Zeitschrift für Untersuchung der Nahrungs- und Genussmittel, Vol. 28,1914 , No. 9, pp. 427-49.

Wines: Herstellung, Lusammensetzung und Beurteilung des Madeiraweines und seiner Ersatzweine. By A. KICKToN AND $R$. MURDFIELD. Zeitschrift für Untersuchung der Nahrungs- und Genussmittel, Vol. 28, 1914, No. 7, pp. 325-64.

wood: Versuch einer Theorie der Trockendestillation ron Holz. I. By PETER KLAson. Journal für praktische Chemie, Vol. 90, 1914, No. 22 , pp. $413-47$

\title{
RECENT INVENTIONS
}

By C. L. PAREer, Solicitor of Chemical Patents, McGill Building, Washington, D. C.

Bleaching Oils \& Fats. C. Baskerville, Oct. 20, I9I4. U. S. Pat. I,I I4,095. The oils and fats to be bleached are subjected to the action of a mixture of Fullers' earth and fibrous cellulosic material.

Revivifying and Preserving Rubber. A. A. Wright, Oct. 27, I9I4. U. S. Pat. I,I 14,84r. The surface of the rubber is subjected to the action of a solution of camphor gum in alcohol admixed with pulverized pumice.

Ammonium Phosphate. F. S. Washburn, Oct. 27, I9I4. U. S. Pat. I, I I5,044. Ammonium phosphate is produced from crude phosphoric acid and gas house liquor by heating the acid to its boiling point, adding the gas house liquor and causing steam to bubble through the mass.

Commercially-Pure Nitrates. C. Bosch and W. Wild, Oct. 27, 19r4. U. S. Pat. I,II5,I64. Commercially pure nitrates are produced by adding limited quantities of water vapor to gaseous mixtures containing the oxids of nitrogen and the gases thus treated are passed over solid basic substances, such as oxids, hydroxids, and carbonates of the alkaline earth metals at such a temperature that the water set free during the combination of the gaseous nitric acid with the base remains in the state of vapor. The temperature should not be above $300^{\circ} \mathrm{C}$.

Concentrating Nitric Acid. F. Hausmann, Oct. 27, I9I4. U. S. Pat. I, II5, 192. Highly concentrated nitric acids up to mono-hydrate are produced by heating a mixture of sulfuric acid and nitric in one thin layer in a distillation

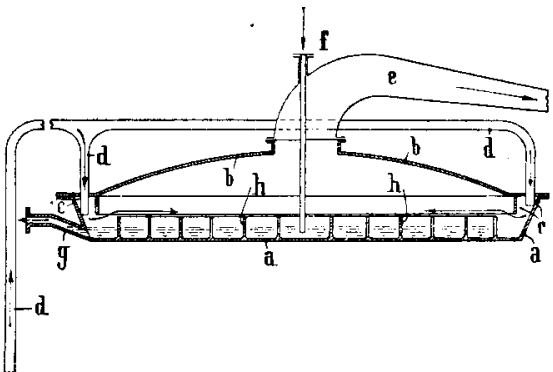
apparatus of the character illustrated.

The heated mixture

moves horizontally in a continuous stream forward through the apparatus while dry, cold air is passed over the surface of the heated mixture and the fumes of nitric acid and air are conducted away from the remaining sulfuric acid.

Detinning Process. J. Weber, Oct. 27, 1914. U. S. Pat. I,I I 5,262. The tin scrap is placed in a closed vessel and treated with chlorin gas at a temperature above that at which the iron of the scrap is attacked. The gases are circulated within the vessel and means are provided to remove the heat generated by the reaction.

Separating the Rare Earths, together with Thorium, Cerium and Zirconium, by Electrolysis. L. M. Dennis, Nov. 3, I914. U. S. Pat. I, II5,5I3. The rare earths are fractionally separated by subjecting an aqueous solution of the salts of the rare earths to the action of an electric current at or above the lowest decomposition voltage of the first product desired and fractionally precipitating insoluble compounds of the rare earths from the solution. The steps are repeated as desired while maintaining the cathode surface free from a covering of the electropositive products of the electrolysis.

Continuous or Constant Electric Discharges in Gases. C. F. R. von Kock, Nov. 3, I9I4. U. S. Pat. I,II5,625. The gases to be subjected to the action of the electric arc are first heated electrically or otherwise, in a suitable chamber as $I$, to a temperature at which they are electrically conductive and are then brought into contact with the arc, the flow of the gases being longitudinally of the are.

Hydrogen. C. Bosch and W. Wild, Nov. 3, I9I4. U. S. Pat. I,II5,776. A gas containing or consisting of carbon monoxid in admixture with steam, is passed over a

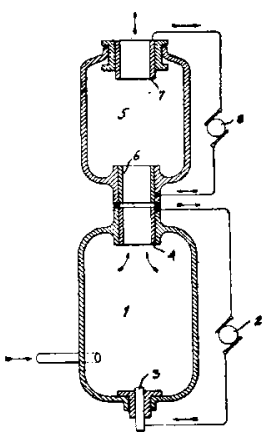
catalytic agent containing divided iron oxid maintained at a temperature below $650^{\circ} \mathrm{C}$.

Reactive Zeolites. T. R. Duggan, Nov. 3, Igr4. U. S. Pat. I,I16,038. A fused glassy melt comprising alumina, silica, potash and soda with a ratio of soda to potash of approximately 